\title{
Common Variable Immunodeficiency
}

\author{
FRANCISCO A. BONILLA AND RAIF S. GEHA
}

Department of Pediatrics, Harvard Medical School, Boston, Massachusetts 02115

\begin{abstract}
Common variable immunodeficiency is the most prevalent clinically significant antibody deficiency at all ages. The disorder is defined principally by characteristic infection susceptibility with hypogammaglobulinemia and impaired-specific antibody response. Several recent large registry-based studies have defined distinct phenotypic subtypes. Several studies have also correlated specific immunologic markers with these phenotypes. The biochemical or genetic abnormality in the majority of patients remains unknown. Recently, several molecular genetic lesions have been defined. Among these, mutations of inducible costimulator, and CD19, appear to be disease causing by themselves. These account for about $1 \%$ of cases. Other mutations or polymorphisms, such as in the human homolog of Escherichia coli MutS 5 (MSH5), and transmembrane activator and calcium mobilizing ligand interactor, seem to be disease associated in 5-10\% of patients, but may require additional immunologic abnormalities for full expression of the phenotype, as unaffected heterozygotes have also been described. (Pediatr Res 65: 13R-19R, 2009)
\end{abstract}

\section{Clinical Features of CVID}

Common variable immunodeficiency (CVID) is a form of predominantly humoral primary immunodeficiency. Symptoms may begin at any time of life, including the extremes of both young and old age (1-3). Major characteristics include recurrent infections, principally bacterial and viral of the respiratory tract. In one recent French registry study (DEFI Study) of 252 patients, $95 \%$ had one or more of the following: bronchitis, sinusitis, and pneumonia. Not surprisingly, common bacterial pathogens such as Streptococcus pneumoniae and Hemophilus influenzae were most often isolated. Granulomatous or lymphocytic interstitial lung disease occurs in a subset of patients and may be associated with human herpesvirus 8 (4). Granulomas may also involve other organs and resemble sarcoid. Furthermore, in the DEFI study, $47 \%$ of patients had diarrhea (intermittent or chronic); Giardia, Salmonella, and Campylobacter were common isolates (2). Enteroviral intestinal infections may disseminate and cause meningoencephalitis.

Autoimmune disease is common in CVID (5). One recent survey reviewed seven published studies comprising 831 patients altogether (6). The reported prevalences of autoimmune disease ranged from 17 to $50 \%$, and it was present in $27 \%$ of the overall patient population. Immune thrombocytopenic pur-

Received November 3, 2008; accepted January 9, 2009

Correspondence: Francisco A. Bonilla, M.D., Ph.D, Children's Hospital Boston, Fegan Building, 6th Floor, 300 Longwood Avenue, Boston, MA 02115; e-mail: francisco.bonilla@childrens.harvard.edu

Supported from Talecris Biotherapeutics, Inc. FAB is a speaker for CSL Behring, Inc. and Baxter International Inc.; consultant for Prescription Solutions, Inc. pura and autoimmune hemolytic anemia were by far the most common diagnoses, followed by aseptic nonerosive seronegative inflammatory arthritis. Additional disorders observed include inflammatory bowel disease, vasculitides (some resembling systemic lupus erythematosus), and others. ${ }^{1}$

Approximately $10 \%$ of patients with CVID have a lymphoproliferative disorder (7). This manifests most frequently as splenomegaly, lymphadenopathy and interstitial lung disease, as described above. The relative risk of lymphoma in patients with CVID compared with the general population is in the range of 10- to 20-fold higher (7). Most of these are B-cell non-Hodgkin lymphoma, although Hodgkin lymphoma is sometimes seen. EBV is found very infrequently (8). A European registry of CVID has collected 334 patients with a cumulative 9461 patient-years of observation (1). These authors distinguish five principle CVID clinical phenotypes: no complications (recurrent infections only), and one or more of the following with or without recurrent infections: autoimmunity, polyclonal lymphocytic infiltration, enteropathy, and lymphoid malignancy. Eighty-three percent of the entire cohort had one of these five phenotypes only, whereas the remainder had two or more complications with or without infections. Survival in the group with infections alone (48\% of all patients) was significantly prolonged in comparison with those with one or more complications.

\section{Immunologic Features of CVID}

By definition, all patients have low serum IgG, often with low IgA and or IgM, and some clear impairment of specific antibody response to infection or vaccine challenge (9). Not surprisingly, with such a relatively nonspecific clinical and laboratory definition (overall), additional immunologic laboratory findings are heterogeneous. In comparison with healthy individuals, B-cell number and in vitro function may be normal or low. CD4 and or CD8 T-cell numbers may also be normal or low. A variety of additional immunologic findings have been reported in relatively small series of patients. The significance of many of these functional abnormalities is unclear, given the underlying heterogeneity of the overall population of patients. Several are listed in Table $1(10-29)$.

Abbreviations: APRIL, a proliferation-inducing ligand; BAFF, B-cell activating factor; CVID, common variable immunodeficiency; ICOS, inducible co-stimulator; MSH5, E. coli MutS homolog 5; TACI, transmembrane activator and calcium-mobilizing ligand interactor 
Table 1. Immunologic abnormalities in patients with CVID in comparison to healthy controls

\begin{tabular}{|c|c|}
\hline Finding & References \\
\hline \multicolumn{2}{|l|}{$\mathrm{T}$ cells } \\
\hline $\begin{array}{l}\text { Impaired thymic } \\
\text { development and } \\
\text { reduced thymic output }\end{array}$ & $(10,11)$ \\
\hline $\begin{array}{l}\text { Altered cytokine } \\
\text { production (various) }\end{array}$ & $(10,12)$ \\
\hline $\begin{array}{l}\text { Altered surface marker } \\
\text { expression }\end{array}$ & $(10,13-15)$ \\
\hline $\begin{array}{l}\text { Altered signal transduction } \\
\text { (decreased expression of } \\
\text { vav) }\end{array}$ & (16) \\
\hline $\begin{array}{l}\text { Impaired signaling via } \\
\text { TNF-RII (TNFRSF1B) }\end{array}$ & (17) \\
\hline $\begin{array}{l}\text { Increased spontaneous } \\
\text { apoptosis }(\mathrm{T} \text {-cell } \\
\text { turnover) }\end{array}$ & (10) \\
\hline Reduced regulatory $\mathrm{T}$ cells & (18) \\
\hline $\begin{array}{l}\text { Reduced naïve CD4 and } \\
\text { CD8 T cells }\end{array}$ & (10) \\
\hline $\begin{array}{l}\text { Restricted } \mathrm{T} \text { cell receptor } \\
\text { beta } \mathrm{V} \text { gene repertoire }\end{array}$ & (10) \\
\hline $\begin{array}{l}\text { Differential gene } \\
\text { expression }\end{array}$ & (10) \\
\hline \multicolumn{2}{|l|}{ B cells } \\
\hline $\begin{array}{l}\text { Altered surface marker } \\
\text { expression }\end{array}$ & $(13,14,19)$ \\
\hline $\begin{array}{l}\text { Altered development of } \\
\text { plasma cells }\end{array}$ & (20) \\
\hline \multicolumn{2}{|l|}{ Monocytes } \\
\hline $\begin{array}{l}\text { Altered cytokine } \\
\text { production }\end{array}$ & (12) \\
\hline \multicolumn{2}{|l|}{ Dendritic cells } \\
\hline $\begin{array}{l}\text { Impaired maturation } \\
\text { (reduced numbers) }\end{array}$ & $(21,22)$ \\
\hline Altered distribution & (23) \\
\hline $\begin{array}{l}\text { Altered cytokine } \\
\text { production }\end{array}$ & $(24,25)$ \\
\hline \multicolumn{2}{|l|}{ Innate immunity } \\
\hline $\begin{array}{l}\text { Impaired signaling via } \\
\text { toll-like receptor } 9\end{array}$ & (26) \\
\hline \multicolumn{2}{|l|}{ Metabolic abnormalities } \\
\hline Vitamin A deficiency & (27) \\
\hline Hypoleptinemia & (28) \\
\hline Insulin resistance & (29) \\
\hline
\end{tabular}

Many reports have focused on identifying more refined immunologic markers to distinguish subsets of patients within CVID or to predict clinical course. We will further describe some potentially useful classification schemes based on immunologic markers that have emerged recently.

Circulating naïve B cells have surface $\operatorname{IgM}$ and $\operatorname{IgD}$. After antigen and T-cell stimulation in germinal centers, they may undergo class switching whereby they lose surface $\operatorname{IgM}$ and $\operatorname{IgD}$ and may express $\operatorname{IgG}, \operatorname{Ig} \mathrm{A}$, or IgE. Memory B cells express the surface marker CD27 (tumor necrosis factor receptor superfamily member 7 or TNFRSF7). Thus, naïve B cells are $\operatorname{IgM}^{+} \operatorname{IgD}^{+} \mathrm{CD}_{27} 7^{-}$; "unswitched" memory B cells are $\operatorname{IgM}^{+} \operatorname{IgD}{ }^{+} \mathrm{CD} 27^{+}$; and "switched" memory B cells are $\mathrm{IgM}^{-} \mathrm{IgD}{ }^{-} \mathrm{CD} 27^{+}$. Memory B cell populations form the basis of a few classification schemes for patients with CVID (Table 2) (30-35). Several additional studies also suggest that reduced percentage of switched memory B cells correlates better with infections and autoimmunity than do serum immunoglobulin and specific antibody responses $(36,37)$. In one such study, females were found to have significantly higher numbers of switched memory B cells in comparison with males (38). The significance of this finding is unknown. At least one study suggests that reduction in unswitched memory B cell numbers also correlates well with clinical complications such as pneumonia (39), although others have not found this association (38).

A large European multicenter trial has recently revisited the matter of CVID classification based on B-cell phenotypes (the EUROclass trial) (40). This study included 303 patients and defined four main groups: those with $<1 \%$ B cells, those whose switched memory B cells were $<2 \%$ of all B cells, and patients with expansion ( $>9 \%$ of all B cells) of transitional $\left(\mathrm{CD} 38^{\mathrm{hi}} \mathrm{IgM}^{\mathrm{hi}}\right) \mathrm{B}$ cells or expansion of CD2 $1^{\text {low }}$ B cells ( $>10 \%$ of all B cells). The most robust statistical associations with phenotypes were a) low switched memory B cells with granuloma; b) expanded transitional B cells and lymphadenopathy; c) expanded $\mathrm{CD} 21^{\text {low }} \mathrm{B}$ cells and splenomegaly.

Low naïve CD4 $\mathrm{T}$ cells correlate well with overall clinical severity and splenomegaly (10). In this study, low serum IgA was the only other major correlate with clinical severity. Low naïve CD4 cells also correlate significantly with the Warnatz classification based on memory B cell phenotypes (Table 2). Low naïve CD4 cells are predominantly in Warnatz groups Ia and Ib (10). However, the concordance between these classification schemes is only approximately $60 \%$. Other abnormalities of T-cell function that predominated in the patients with the lowest naïve CD4 cell numbers included a high degree of T-cell activation exhibited by expression of CD95 (Fas) and HLA-DR, the highest rates of proliferation and apoptosis, and the greatest restriction in $\mathrm{T}$-cell receptor $\mathrm{V}$ beta gene repertoire. In patients in the lowest tertile of naïve CD4 cell number, these authors found significantly increased expression of mRNA for CD9 and CREB1 (cAMP response element binding, 11-fold and 5-fold, respectively), and reduced expression of HCFC1 (host cell factor C1, 14-fold).

Both myeloid and plasmacytoid dendritic cell populations are reduced in CVID (21). The number of dendritic cells correlates with total number of B cells and percentage of switched memory cells. As has been seen in other studies, they also correlate with clinical features such as infections, granulomatous disease, autoimmunity, splenomegaly, etc. In the European registry study, only limited immunologic correlations with phenotypes were sought (1). Increased IgM was associated with lymphocytic infiltration and malignancy; increased CD8 cells were inversely related to the risk for autoimmune disease.

\section{Diagnosis}

Given the nonspecific nature of the clinical presentation and fundamental laboratory definition of CVID, the diagnosis remains predominantly one of exclusion. In the adult group in 
Table 2. Classifications of CVID based on memory B cell phenotype

\begin{tabular}{|c|c|c|c|c|c|c|c|}
\hline $\begin{array}{l}\text { Classification } \\
\text { scheme }\end{array}$ & Group & Memory B cells & $\begin{array}{l}\text { Splenomegaly } \\
\text { or LPD* }\end{array}$ & $\begin{array}{l}\text { Granulo } \\
\text { mas }\end{array}$ & $\begin{array}{l}\text { Auto } \\
\text { immunity }\end{array}$ & $\begin{array}{c}\text { Serum } \\
\text { immunoglobulin }\end{array}$ & $\begin{array}{l}\text { Specific } \\
\text { antibody }\end{array}$ \\
\hline \multirow[t]{3}{*}{ Piqueras et al. (34) } & MB0 & All CD $27^{+}$low & + & + & + & & \\
\hline & MB1 & Low $\operatorname{IgM} / \mathrm{D}^{-} \mathrm{CD} 27^{+}$ & + & + & + & Very low & Very low \\
\hline & MB2 & Normal & & & + & Low & Low \\
\hline \multirow[t]{3}{*}{ Warnatz et al. (35) } & Ia & $\begin{array}{c}\text { Low } \operatorname{IgM} / \mathrm{D}^{-} \mathrm{CD} 27^{+} \\
\text {and low } \mathrm{CD} 21\end{array}$ & + & + & + & Very low & Very low \\
\hline & $\mathrm{Ib}$ & $\begin{array}{l}\text { Low IgM/D }{ }^{-} \mathrm{CD} 27^{+} \\
\text {and normal CD21 }\end{array}$ & & + & + & Very low & Very low \\
\hline & II & Normal & & & + & Low & Low \\
\hline
\end{tabular}

LPD, lymphoproliferative disease.

particular, secondary immunodeficiencies must be excluded. Although nonspecific, the main diagnostic criteria are, at least, straightforward. Thus, it may be surprising that many patients are ill for many years before the diagnosis is made. It seems most likely this is due to lack of recognition on the part of clinicians.

In the European registry study, the mean and median ages at onset of symptoms were 26.3 and $24 \mathrm{y}$, respectively (1). At diagnosis, these ages were 35.3 and $33 \mathrm{y}$, respectively. The mean and median years of delay between symptom onset and diagnosis were 7.5 and 5, respectively (range 0-61 y). Twenty percent of patients were diagnosed more than $15 \mathrm{y}$ of the onset of symptoms, and there was an inverse correlation between the age of onset and the delay in diagnosis. In the DEFI study, the median age at onset of symptoms was $19 \mathrm{y}$, and median age at diagnosis was $33.9 \mathrm{y}$ (2). The delay in diagnosis was greatest for patients identified before 1990, in comparison with those diagnosed after 1990, suggesting increased awareness and screening for hypogammaglobulinemia in adults presenting with recurrent infections. Nevertheless, the median delay in diagnosis after the onset of symptoms was still 2.9 y even in the group diagnosed after 1990. In an Italian study of 224 patients with CVID, the mean age at onset was $16.9 \mathrm{y}$ and mean age at diagnosis was $26.6 \mathrm{y}$ (mean delay 8.9 y) (3).

It may be said that individuals are "misdiagnosed" with CVID, if they are ultimately found to have a molecular defect associated with a previously defined and distinct primary immunodeficiency syndrome. This has occurred in patients with mutations of Bruton's tyrosine kinase (BTK, associated with X-linked agammaglobulinemia) $(41,42)$, SLAMassociated protein or SAP (encoded by SH2D1A and associated with X-linked lymphoproliferative syndrome) (43). On the other hand, mutations or polymorphisms in several genes not previously associated with primary immunodeficiency have been described in the CVID population, and these patients are said to have CVID (possibly) due to, or associated with, mutations of these genes. They include inducible T-cell costimulator (ICOS), CD19, the human homolog of Escherichia coli MutS 5 (MSH5), and transmembrane activator and calcium mobilizing ligand interactor (TACI), also called tumor necrosis factor receptor superfamily member 13B (TNFRSF13B).

\section{ICOS Deficiency}

A total of nine individuals worldwide have been found to have mutations of ICOS (44). All of these individuals have the same founder mutation (deletion of a large segment of the gene) arising originally in the Black Forest region of Germany. These patients have recurrent infections without the autoimmune, lymphoproliferative or malignant complications often seen in CVID. All but one had adult onset of symptoms. These patients have panhypogammaglobulinemia, poor vaccine responses, and low B cells, including the memory subset. Thus, they represent a discordance from the association of low memory B cells and noninfectious complications of CVID observed in the larger population.

ICOS is a member of the CD28 family and interacts with a member of the B7 group of molecules known as ICOS ligand. ICOS is induced on $\mathrm{T}$ cells after activation, whereas ICOS ligand is expressed constitutively on antigen-presenting cells and $\mathrm{B}$ cells. This signaling pathway leads to increased production of IL-10, important for terminal B-cell development into memory B cells and plasma cells. ICOS is also important for activation of helper $\mathrm{T}$ cells and cognate $\mathrm{T}$ cell help for antibody production (45). ICOS-L knockout mice have the same phenotype as ICOS knockouts (46). To date, ICOS-L mutations have not been identified in patients with CVID.

\section{CD19 Deficiency}

Five patients with recurrent infections, hypogammaglobulinemia, poor vaccine responses, and low memory B cells have been found to have mutations in CD19 $(47,48)$. All patients had onset of symptoms in the first decade of life, and developed thrombocytopenia. CD19 is a component of a B-cell signaling complex. It is expressed in association with CD21 (also called complement receptor 2, or CR2), CD81 (TAPA-1) and CD225 (Leu-13, or interferon-induced transmembrane protein 1). The physiologic ligand of CD21 is the C3 component of complement fragment C3dg; it is also the EBV receptor. CD19 signals via the Lyn tyrosine kinase and the CD19 complex reduces the threshold for B-cell activation via the immunoglobulin receptor.

\section{Polymorphisms of MSH5}

Selective IgA deficiency is a distinct diagnostic entity that shares some clinical features with CVID (49). Some patients 
with IgA deficiency may progress over time to CVID. CVID and IgA deficiency have been associated with HLA haplotypes A1-B8-DR3, B14-DR1, and B44-DR7 (50,51). As many as $13 \%$ of patients homozygous for A1-B8-DR3 may be IgA deficient. The peripheral blood B cell number is statistically somewhat higher in patients with either of these HLA-B alleles (independent of DR) in comparison with those with other HLA-B types (50).

MSH5 has roles in meiosis, DNA mismatch repair, and immunoglobulin class switching (51). Recently, polymorphisms in MSH5 have been found in some patients with CVID and selective IgA deficiency. The MSH5 gene is in the class III MHC locus, and these polymorphisms are associated with the A1-B8-DR3 extended haplotype. Although these polymorphisms occur with greater frequency in affected patients, they are also found in healthy individuals, and functional consequences have not yet been demonstrated. Additional disease determinants in these patients have not yet been identified.

\section{TACI Deficiency}

Between 5 and $10 \%$ of patients with CVID are either homozygous or heterozygous for mutations of TACI, whose official designation is tumor necrosis factor receptor superfamily member 13B, or TNFRSF13B (52-55). The A181E and C104R mutations in the transmembrane and extracellular regions of TACI, respectively, have been particularly associated with disease in heterozygotes (and homozygotes). However, the pathogenetic role of these (and other) mutations still requires clarification. Some heterozygotes may be asymptomatic $(56,57)$.

TACI is an element of a complex intercellular signaling system involving a subset of the tumor necrosis factor/tumor necrosis factor receptor (TNF/TNFR) superfamilies. These interactions are summarized in Figure 1. TACI is expressed on B cells after activation by a variety of stimuli such as ligation of toll-like receptor 9, ligation of $\operatorname{IgM}$, and signaling via CD40, also interleukins-2 and -10; expression persists on memory B cells and plasma cells $(58,59)$. TACI expression is

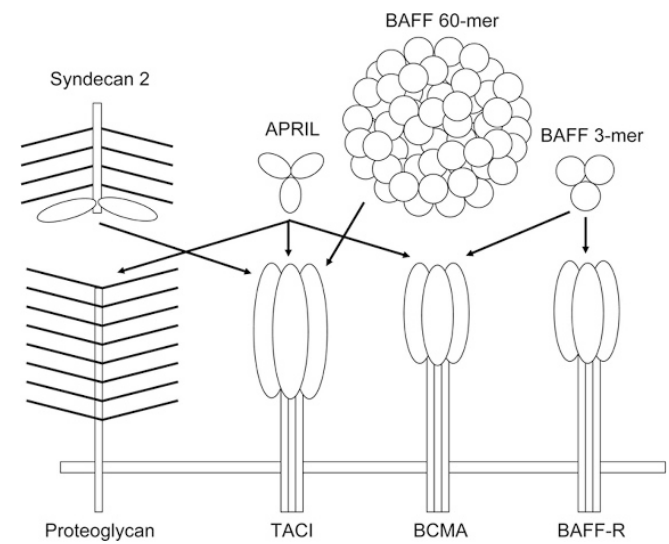

Figure 1. Signaling interactions among TACI, related receptors, and their ligands. BCMA is B-cell maturation factor, also tumor necrosis factor receptor superfamily member 17 (TNFRSF17). See text for other abbreviations and details. prominent in marginal zone B cells and a subset of $\mathrm{CD} 27^{+} \mathrm{B}$ cells $(59,60)$. TACI may also be found on activated T cells, monocytes, and dendritic cells (61).

TACI ligands BAFF (B-cell activating factor, TNFSF13B) and a proliferation-inducing ligand (APRIL, TNFSF13) are expressed on macrophages and dendritic cells (58). BAFF is also expressed on neutrophils and APRIL is also expressed on some activated $\mathrm{T}$ cells. The multimeric (60-mer) form of BAFF exclusively signals via TACI, whereas BAFF-R (expressed exclusively on B cells) also can signal after ligation by soluble BAFF 3-mer (Fig. 1) (62). TACI also interacts with the proteoglycan syndecan-2 (63). Signaling between TACI and its ligands influences B cell activation, survival, class switching, and memory B cell formation.

Note that CD40 is also a member of the TNFR superfamily (it is TNFRSF5) and CD40 ligand (CD0L, also called CD154) is TNFSF5. CD40 is expressed on B cells and mononuclear cells including dendritic cells, and endothelial cells, whereas CD40L is expressed on activated T cells. CD40-CD40L interactions are entirely distinct from those in the TACI system, and there is no cross-interaction. In mucosal tissues B cells are in proximity to dendritic and epithelial cells that may express BAFF and APRIL in response to signals generated via tolllike receptors (64). This permits rapid $\mathrm{T}$ cell independent immunoglobulin production. In contrast, in secondary lymphoid tissues such as spleen or lymph nodes, B cells are in proximity to $\mathrm{T}$ cells and receive signals via $\mathrm{CD} 40 \mathrm{~L}$ leading to germinal center formation and T-dependent immunoglobulin production (65). TACI can mediate class switching to IgA, though to a lesser degree than CD40 (66). Signals delivered through TACI also amplify plasma cell differentiation and immunoglobulin production after CD40 or toll-like receptor signaling (67).

TACI-deficient mice have low serum IgA and impaired antibody response to thymus-independent type 2 antigens (normally generated in the absence of cognate $\mathrm{T}$ cell help for B cells) (68). Although TACI has important roles as a coactivator with various signals, it also regulates B-cell expansion. TACI-deficient mice have increased numbers of circulating B cells and splenomegaly and are prone to autoimmunity and lymphoma $(68,69)$.

The intracellular domain of TACI associates with various TNF receptor associated factors 2 and 3 (TRAFs 2 and 3) and calcium-mobilizing ligand (CAML) (58). Downstream intermediates link TACI to pathways through the nuclear factor kappa B (NF- $\kappa \mathrm{B})$, and the transcription factors nuclear factor of activated $\mathrm{T}$ cells (NF-AT), and activator protein-1 (AP-1). The mechanistic links between CD40, TACI, and BAFF-R to class switching are not yet clear. Association with TRAF2 and TRAF3 is necessary, but not sufficient because many other TNFRs signal through these intermediates and do not promote class switching. Another pathway associated with TACI involves CAML, which enables calcium mobilization during cellular activation. Additional signaling pathways linked to CD40 mediating class switching have not yet been described.

TACI forms multimeric complexes before ligand binding (70). The human C104R mutant (and the murine C76R ho- 
molog) does not bind ligand (BAFF) but can form multimers with wild-type TACI. Although the mutant TACI molecules do not inhibit ligand binding by the wild-type TACI, downstream NFkB signaling is blocked by this association.

Patients with CVID with TACI mutations may exhibit the full spectrum of clinical complications including recurrent infections, autoimmune disease, lymphoproliferation, and lymphoma, low IgG with or without low IgA, poor responses to vaccines (particularly pneumococcal polysaccharides), low B-cell number and low switched memory B cells. One study of 176 patients with CVID identified 13 (7.6\%) heterozygous for various TACI mutations (57). The rates of autoimmune thrombocytopenia and splenomegaly were significantly increased in this group, in comparison with patients with CVID without TACI mutations. Defective responses to stimulation with APRIL in vivo were noted in some TACI-mutant patients, but this was also observed in patients without TACI mutations. Altogether, eight healthy first-degree relatives were heterozygous for the same mutations and had normal responses to APRIL. Additional disease-defining genetic or environmental determinants have not been described in these individuals to explain the variable penetrance of TACI mutation. In a separate study, the serum of 77 patients with CVID was found to have significantly elevated levels of TACI, BAFF, and APRIL in comparison with a group of 21 controls (71). However, within the patients, the levels did not correlate with clinical, immunologic laboratory or genetic (TACI mutation) phenotypes.

There may be different functional consequences of distinct TACI mutations and some may act in a dominant negative manner and others may impair signaling by haploinsufficiency. However, deleterious TACI mutations alone cannot be said to be disease causing because they are found in $1 \%$ of the general population including apparently healthy first-degree relatives of patients with CVID (see above). No candidate genes modifying expression of TACI mutation have yet been described.

Newborn mice express very little TACI and do not respond to BAFF and APRIL (72) The same is true of preterm and newborn humans (73). This may underlie or contribute to the relatively low responsiveness to polysaccharide antigens (for example, pneumococcal capsule) in newborns. The defect can be abrogated by coupling $\mathrm{CpG}$ oligodeoxynucleotides (TLR9 agonists) to polysaccharide immunogens (72).

The adenovirus E3-6.7 $\mathrm{K}$ protein may be a viral homolog of TACI (74). The E3-6.7 K protein binds to and colocalizes with CAML in an endoplasmic reticulum compartment and can inhibit calcium flux and apoptosis. This could be a mechanism for enhancing survival of infected cells.

Atacicept is a TACI-immunoglobulin fusion protein that has been developed for potential therapy of autoimmune disease (trials have included systemic lupus erythematosus and rheumatoid arthritis) and B cell lymphomas (75-78). The rationale for autoimmune disease is to inhibit signaling via BAFF and APRIL and hopefully to diminish ongoing autoimmune B cell activation. In the setting of B cell malignancy, BAFF and APRIL are often overexpressed and could provide a survival or proliferation signal mediated by TACI. Treated patients have exhibited declines in serum $\operatorname{IgG}$ and $\mathrm{B}$ cell numbers. The drug is well tolerated, but its efficacy in any of these diseases is not yet established.

\section{Conclusion}

Despite the descriptions of molecular defects in subsets of patients with CVID, more than $90 \%$ of cases are due to mechanisms that have not yet been described. As our understanding grows regarding signaling via TACI, related receptors, and BAFF and APRIL, the final common pathway may soon come to light. Even if the final answers lie elsewhere, this is yet another example where study of primary immunodeficiency yields fundamental breakthroughs that may have far-reaching consequences for understanding of and intervention in other diseases.

\section{REFERENCES}

1. Chapel H, Lucas M, Lee M, Bjorkander J, Webster D, Grimbacher B, Fieschi C, Thon V, Abedi MR, Hammarstrom L 2008 Common variable immunodeficiency disorders: division into distinct clinical phenotypes. Blood 112:277-286

2. Oksenhendler E, Gerard L, Fieschi C, Malphettes M, Mouillot G, Jaussaud R, Viallard JF, Gardembas M, Galicier L, Schleinitz N, Suarez F, Soulas-Sprauel P, Hachulla E, Jaccard A, Gardeur A, Theodorou I, Rabian C, Debre P 2008 Infections in 252 patients with common variable immunodeficiency. Clin Infect Dis 46:15471554

3. Quinti I, Soresina A, Spadaro G, Martino S, Donnanno S, Agostini C, Claudio P, Franco D, Maria Pesce A, Borghese F, Guerra A, Rondelli R, Plebani A 2007 Long-term follow-up and outcome of a large cohort of patients with common variable immunodeficiency. J Clin Immunol 27:308-316

4. Wheat WH, Cool CD, Morimoto Y, Rai PR, Kirkpatrick CH, Lindenbaum BA, Bates CA, Ellison MC, Serls AE, Brown KK, Routes JM 2005 Possible role of human herpesvirus 8 in the lymphoproliferative disorders in common variable immunodeficiency. J Exp Med 202:479-484

5. Cunningham-Rundles C 2008 Autoimmune manifestations in common variable immunodeficiency. J Clin Immunol 28:S42-S45

6. Lopes-da-Silva S, Rizzo LV 2008 Autoimmunity in common variable immunodeficiency. J Clin Immunol 28:S46-S55

7. Chua I, Quinti I, Grimbacher B 2008 Lymphoma in common variable immunodeficiency: interplay between immune dysregulation, infection and genetics. Curr Opin Hematol 15:368-374

8. Gompels MM, Hodges E, Lock RJ, Angus B, White H, Larkin A, Chapel HM, Spickett GP, Misbah SA, Smith JL 2003 Lymphoproliferative disease in antibody deficiency: a multi-centre study. Clin Exp Immunol 134:314-320

9. Conley ME, Notarangelo LD, Etzioni A 1999 Diagnostic criteria for primary immunodeficiencies. Representing PAGID (Pan-American Group for Immunodeficiency) and ESID (European Society for Immunodeficiencies). Clin Immunol 93:190-197

10. Giovannetti A, Pierdominici M, Mazzetta F, Marziali M, Renzi C, Mileo AM, De Felice M, Mora B, Esposito A, Carello R, Pizzuti A, Paggi MG, Paganelli R, Malorni W, Aiuti F 2007 Unravelling the complexity of T cell abnormalities in common variable immunodeficiency. J Immunol 178:3932-3943

11. De Vera MJ, Al-Harthi L, Gewurz AT 2004 Assessing thymopoiesis in patients with common variable immunodeficiency as measured by T-cell receptor excision circles. Ann Allergy Asthma Immunol 93:478-484

12. Zhou Z, Huang R, Danon M, Mayer L, Cunningham-Rundles C 1998 IL-10 production in common variable immunodeficiency. Clin Immunol Immunopathol $86: 298-304$

13. Vlkova M, Thon V, Sarfyova M, Blaha L, Svobodnik A, Lokaj J, Litzman J 2006 Age dependency and mutual relations in $\mathrm{T}$ and $\mathrm{B}$ lymphocyte abnormalities in common variable immunodeficiency patients. Clin Exp Immunol 143:373-379

14. Viallard JF, Blanco P, Andre M, Etienne G, Liferman F, Neau D, Vidal E, Moreau JF, Pellegrin JL 2006 CD8+HLA-DR+ T lymphocytes are increased in common variable immunodeficiency patients with impaired memory B-cell differentiation. Clin Immunol 119:51-58

15. Moratto D, Gulino AV, Fontana S, Mori L, Pirovano S, Soresina A, Meini A, Imberti L, Notarangelo LD, Plebani A, Badolato R 2006 Combined decrease of defined B and $\mathrm{T}$ cell subsets in a group of common variable immunodeficiency patients. Clin Immunol 121:203-214

16. Paccani SR, Boncristiano M, Patrussi L, Ulivieri C, Wack A, Valensin S, Hirst TR, Amedei A, Del Prete G, Telford JL, D'Elios MM, Baldari CT 2005 Defective Vav expression and impaired F-actin reorganization in a subset of patients with common variable immunodeficiency characterized by $\mathrm{T}$-cell defects. Blood 106:626-634

17. Aspalter RM, Eibl MM, Wolf HM 2007 Defective T-cell activation caused by impairment of the TNF receptor 2 costimulatory pathway in common variable immunodeficiency. J Allergy Clin Immunol 120:1193-1200 
18. Fevang B, Yndestad A, Sandberg WJ, Holm AM, Muller F, Aukrust P, Froland SS 2007 Low numbers of regulatory $\mathrm{T}$ cells in common variable immunodeficiency: association with chronic inflammation in vivo. Clin Exp Immunol 147:521-525

19. Denz A, Eibel H, Illges H, Kienzle G, Schlesier M, Peter HH 2000 Impaired up-regulation of CD86 in B cells of "type A" common variable immunodeficiency patients. Eur J Immunol 30:1069-1077

20. Taubenheim N, von Hornung M, Durandy A, Warnatz K, Corcoran L, Peter HH, Eibel H 2005 Defined blocks in terminal plasma cell differentiation of common variable immunodeficiency patients. J Immunol 175:5498-5503

21. Yong PF, Workman S, Wahid F, Exley A, Webster AD, Ibrahim MA 2008 Selective deficits in blood dendritic cell subsets in common variable immunodeficiency and $\mathrm{X}$-linked agammaglobulinaemia but not specific polysaccharide antibody deficiency. Clin Immunol 127:34-42

22. Scott-Taylor TH, Green MR, Raeiszadeh M, Workman S, Webster AD 2006 Defective maturation of dendritic cells in common variable immunodeficiency. Clin Exp Immunol 145:420-427

23. Viallard JF, Camou F, Andre M, Liferman F, Moreau JF, Pellegrin JL, Blanco P 2005 Altered dendritic cell distribution in patients with common variable immunodeficiency. Arthritis Res Ther 7:R1052-R1055

24. Cunningham-Rundles C, Radigan L 2005 Deficient IL-12 and dendritic cell function in common variable immune deficiency. Clin Immunol 115:147-153

25. Bayry J, Lacroix-Desmazes S, Kazatchkine MD, Galicier L, Lepelletier Y, Webster D, Levy Y, Eibl MM, Oksenhendler E, Hermine O, Kaveri SV 2004 Common variable immunodeficiency is associated with defective functions of dendritic cells Blood 104:2441-2443

26. Cunningham-Rundles C, Radigan L, Knight AK, Zhang L, Bauer L, Nakazawa A 2006 TLR9 activation is defective in common variable immune deficiency. J Immunol 176:1978-1987

27. Kilic SS, Kezer EY, Ilcol YO, Yakut T, Aydin S, Ulus IH 2005 Vitamin a deficiency in patients with common variable immunodeficiency. J Clin Immunol 25:275-280

28. Ferraroni NR, Geloneze B, Mansour E, Perroud AP, Muscelli EO, Tambascia M, de Lima Zollner R, Velloso LA 2005 Severe hypoleptinaemia associated with insulin resistance in patients with common variable immunodeficiency. Clin Endocrinol (Oxf) 63:63-65

29. Goldberg AC, Eliaschewitz FG, Montor WR, Baracho GV, Errante PR, Callero MA, Cardoso MR, Braga PE, Kalil J, Sogayar MC, Rizzo LV 2005 Exogenous leptin restores in vitro $\mathrm{T}$ cell proliferation and cytokine synthesis in patients with common variable immunodeficiency syndrome. Clin Immunol 114:147-153

30. Agematsu K, Nagumo H, Shinozaki K, Hokibara S, Yasui K, Terada K, Kawamura N, Toba T, Nonoyama S, Ochs HD, Komiyama A 1998 Absence of IgD-CD27(+) memory B cell population in X-linked hyper-IgM syndrome. J Clin Invest 102:853860

31. Alachkar H, Taubenheim N, Haeney MR, Durandy A, Arkwright PD 2006 Memory switched B cell percentage and not serum immunoglobulin concentration is associated with clinical complications in children and adults with specific antibody deficiency and common variable immunodeficiency. Clin Immunol 120:310-318

32. Ferry BL, Jones J, Bateman EA, Woodham N, Warnatz K, Schlesier M, Misbah SA, Peter HH, Chapel HM 2005 Measurement of peripheral B cell subpopulations in common variable immunodeficiency (CVID) using a whole blood method. Clin Exp Immunol 140:532-539

33. Ko J, Radigan L, Cunningham-Rundles C 2005 Immune competence and switched memory B cells in common variable immunodeficiency. Clin Immunol 116:37-41

34. Piqueras B, Lavenu-Bombled C, Galicier L, Bergeron-van der Cruyssen F, Mouthon L, Chevret S, Debre P, Schmitt C, Oksenhendler E 2003 Common variable immunodeficiency patient classification based on impaired $\mathrm{B}$ cell memory differentiation correlates with clinical aspects. J Clin Immunol 23:385-400

35. Warnatz K, Denz A, Drager R, Braun M, Groth C, Wolff-Vorbeck G, Eibel H, Schlesier M, Peter HH 2002 Severe deficiency of switched memory B cells $(\mathrm{CD} 27(+) \operatorname{IgM}(-) \operatorname{IgD}(-))$ in subgroups of patients with common variable immunodeficiency: a new approach to classify a heterogeneous disease. Blood 99:15441551

36. Berglund LJ, Wong SW, Fulcher DA 2008 B-cell maturation defects in common variable immunodeficiency and association with clinical features. Pathology 40:288-294

37. Detkova D, de Gracia J, Lopes-da-Silva S, Vendrell M, Alvarez A, Guarner L, Vidaller A, Rodrigo MJ, Caragol I, Espanol T, Hernandez M 2007 Common variable immunodeficiency: association between memory B cells and lung diseases. Chest 131:1883-1889

38. Sanchez-Ramon S, Radigan L, Yu JE, Bard S, Cunningham-Rundles C 2008 Memory B cells in common variable immunodeficiency: clinical associations and sex differences. Clin Immunol 128:314-321

39. Carsetti R, Rosado MM, Donnanno S, Guazzi V, Soresina A, Meini A, Plebani A Aiuti F, Quinti I 2005 The loss of IgM memory B cells correlates with clinical disease in common variable immunodeficiency. J Allergy Clin Immunol 115:412417

40. Wehr C, Kivioja T, Schmitt C, Ferry B, Witte T, Eren E, Vlkova M, Hernandez M, Detkova D, Bos PR, Poerksen G, von Bernuth H, Baumann U, Goldacker S, Gutenberger S, Schlesier M, Bergeron-van der Cruyssen F, Le Garff M, Debre P, Jacobs R, Jones J, Bateman E, Litzman J, van Hagen PM, Plebani A, Schmidt RE, Thon V, Quinti I, Espanol T, Webster AD, Chapel H, Vihinen M, Oksenhendler E, Peter HH, Warnatz K 2008 The EUROclass trial: defining subgroups in common variable immunodeficiency. Blood 111:77-85

41. Kanegane H, Tsukada S, Iwata T, Futatani T, Nomura K, Yamamoto J, Yoshida T, Agematsu K, Komiyama A, Miyawaki T 2000 Detection of Bruton's tyrosine kinase mutations in hypogammaglobulinaemic males registered as common variable im- munodeficiency (CVID) in the Japanese Immunodeficiency Registry. Clin Exp Immunol 120:512-517

42. Stewart DM, Tian L, Nelson DL 2001 A case of x-linked agammaglobulinemia diagnosed in adulthood. Clin Immunol 99:94-99

43. Morra M, Silander O, Calpe S, Choi M, Oettgen H, Myers L, Etzioni A, Buckley R, Terhorst C 2001 Alterations of the X-linked lymphoproliferative disease gene SH2D1A in common variable immunodeficiency syndrome. Blood 98:1321-1325

44. Salzer U, Maul-Pavicic A, Cunningham-Rundles C, Urschel S, Belohradsky BH, Litzman J, Holm A, Franco JL, Plebani A, Hammarstrom L, Skrabl A, Schwinger W, Grimbacher B 2004 ICOS deficiency in patients with common variable immunodeficiency. Clin Immunol 113:234-240

45. Carreno BM, Collins M 2002 The B7 family of ligands and its receptors: new pathways for costimulation and inhibition of immune responses. Annu Rev Immuno 20:29-53

46. Wong SC, Oh E, Ng CH, Lam KP 2003 Impaired germinal center formation and recall $\mathrm{T}$-cell-dependent immune responses in mice lacking the costimulatory ligand B7-H2. Blood 102:1381-1388

47. Kanegane H, Agematsu K, Futatani T, Sira MM, Suga K, Sekiguchi T, van Zelm MC, Miyawaki T 2007 Novel mutations in a Japanese patient with CD19 deficiency. Genes Immun 8:663-670

48. van Zelm MC, Reisli I, van der Burg M, Castano D, van Noesel CJ, van Tol MJ, Woellner C, Grimbacher B, Patino PJ, van Dongen JJ, Franco JL 2006 An antibodydeficiency syndrome due to mutations in the CD19 gene. N Engl J Med 354:19011912

49. Hammarstrom L, Vorechovsky I, Webster D 2000 Selective IgA deficiency (SIgAD) and common variable immunodeficiency (CVID). Clin Exp Immunol 120:225-231

50. Johnston DT, Schroeder HW Jr 2007 B-cell numbers in the blood of patients with non-HLA*B8 or non-HLA*B44 common variable immunodeficiency. Ann Allergy Asthma Immunol 98:163-167

51. Sekine H, Ferreira RC, Pan-Hammarstrom Q, Graham RR, Ziemba B, de Vries SS, Liu J, Hippen K, Koeuth T, Ortmann W, Iwahori A, Elliott MK, Offer S, Skon C, Du L, Novitzke J, Lee AT, Zhao N, Tompkins JD, Altshuler D, Gregersen PK, Cunningham-Rundles C, Harris RS, Her C, Nelson DL, Hammarstrom L, Gilkeson GS, Behrens TW 2007 Role for Msh5 in the regulation of Ig class switch recombination. Proc Natl Acad Sci U S A 104:7193-7198

52. Castigli E, Wilson SA, Garibyan L, Rachid R, Bonilla F, Schneider L, Geha RS 2005 TACI is mutant in common variable immunodeficiency and $\operatorname{IgA}$ deficiency. Nat Genet 37:829-834

53. Salzer U, Chapel HM, Webster AD, Pan-Hammarstrom Q, Schmitt-Graeff A Schlesier M, Peter HH, Rockstroh JK, Schneider P, Schaffer AA, Hammarstrom L, Grimbacher B 2005 Mutations in TNFRSF13B encoding TACI are associated with common variable immunodeficiency in humans. Nat Genet 37:820-828

54. Bacchelli C, Buckridge S, Thrasher AJ, Gaspar HB 2007 Translational mini-review series on immunodeficiency: molecular defects in common variable immunodeficiency. Clin Exp Immunol 149:401-409

55. Rachid R, Castigli E, Geha RS, Bonilla FA 2006 TACI mutation in common variable immunodeficiency and IgA deficiency. Curr Allergy Asthma Rep 6:357-362

56. Pan-Hammarstrom Q, Salzer U, Du L, Bjorkander J, Cunningham-Rundles C, Nelson DL, Bacchelli C, Gaspar HB, Offer S, Behrens TW, Grimbacher B, Hammarstrom L 2007 Reexamining the role of TACI coding variants in common variable immunodeficiency and selective IgA deficiency. Nat Genet 39:429-430

57. Zhang L, Radigan L, Salzer U, Behrens TW, Grimbacher B, Diaz G, Bussel J, Cunningham-Rundles C 2007 Transmembrane activator and calcium-modulating cyclophilin ligand interactor mutations in common variable immunodeficiency: clinical and immunologic outcomes in heterozygotes. J Allergy Clin Immunol 120:1178-1185

58. Mackay F, Schneider P 2008 TACI, an enigmatic BAFF/APRIL receptor, with new unappreciated biochemical and biological properties. Cytokine Growth Factor Rev 19:263-276

59. Darce JR, Arendt BK, Wu X, Jelinek DF 2007 Regulated expression of BAFFbinding receptors during human B cell differentiation. J Immunol 179:7276-7286

60. Ng LG, Sutherland AP, Newton R, Qian F, Cachero TG, Scott ML, Thompson JS, Wheway J, Chtanova T, Groom J, Sutton IJ, Xin C, Tangye SG, Kalled SL, Mackay F, Mackay CR 2004 B cell-activating factor belonging to the TNF family (BAFF)-R is the principal BAFF receptor facilitating BAFF costimulation of circulating $\mathrm{T}$ and B cells. J Immunol 173:807-817

61. Chang SK, Mihalcik SA, Jelinek DF 2008 B lymphocyte stimulator regulates adaptive immune responses by directly promoting dendritic cell maturation. J Immunol 180:7394-7403

62. Bossen C, Cachero TG, Tardivel A, Ingold K, Willen L, Dobles M, Scott ML, Maquelin A, Belnoue E, Siegrist CA, Chevrier S, Acha-Orbea H, Leung H, Mackay F, Tschopp J, Schneider P 2008 TACI, unlike BAFF-R, is solely activated by oligomeric BAFF and APRIL to support survival of activated B cells and plasmablasts. Blood 111:1004-1012

63. Bischof D, Elsawa SF, Mantchev G, Yoon J, Michels GE, Nilson A, Sutor SL, Plat JL, Ansell SM, von Bulow G, Bram RJ 2006 Selective activation of TACI by syndecan-2. Blood 107:3235-3242

64. Xu W, Santini PA, Matthews AJ, Chiu A, Plebani A, He B, Chen K, Cerutti A 2008 Viral double-stranded RNA triggers Ig class switching by activating upper respiratory mucosa B cells through an innate TLR3 pathway involving BAFF. J Immunol 181:276-287

65. Basso K, Klein U, Niu H, Stolovitzky GA, Tu Y, Califano A, Cattoretti G, Dalla-Favera R 2004 Tracking CD40 signaling during germinal center development. Blood 104:4088-4096

66. Castigli E, Wilson SA, Scott S, Dedeoglu F, Xu S, Lam KP, Bram RJ, Jabara H, Geha RS 2005 TACI and BAFF-R mediate isotype switching in B cells. J Exp Med 201:35-39 
67. Castigli E, Wilson SA, Elkhal A, Ozcan E, Garibyan L, Geha RS 2007 Transmembrane activator and calcium modulator and cyclophilin ligand interactor enhances CD40-driven plasma cell differentiation. J Allergy Clin Immunol 120:885-891

68. von Bulow GU, van Deursen JM, Bram RJ 2001 Regulation of the T-independent humoral response by TACI. Immunity 14:573-582

69. Seshasayee D, Valdez P, Yan M, Dixit VM, Tumas D, Grewal IS 2003 Loss of TAC causes fatal lymphoproliferation and autoimmunity, establishing TACI as an inhibitory BLyS receptor. Immunity 18:279-288

70. Garibyan L, Lobito AA, Siegel RM, Call ME, Wucherpfennig KW, Geha RS 2007 Dominant-negative effect of the heterozygous C104R TACI mutation in common variable immunodeficiency (CVID). J Clin Invest 117:1550-1557

71. Knight AK, Radigan L, Marron T, Langs A, Zhang L, Cunningham-Rundles C 2007 High serum levels of BAFF, APRIL, and TACI in common variable immunodeficiency. Clin Immunol 124:182-189

72. Kanswal S, Katsenelson N, Selvapandiyan A, Bram RJ, Akkoyunlu M 2008 Deficient TACI expression on B lymphocytes of newborn mice leads to defective Ig secretion in response to BAFF or APRIL. J Immunol 181:976-990

73. Kaur K, Chowdhury S, Greenspan NS, Schreiber JR 2007 Decreased expression of tumor necrosis factor family receptors involved in humoral immune responses in preterm neonates. Blood 110:2948-2954
74. Grant JR, Moise AR, Jefferies WA 2007 Identification of a novel immunosubversion mechanism mediated by a virologue of the B-lymphocyte receptor TACI. Clin Vaccine Immunol 14:907-917

75. Ansell SM, Witzig TE, Inwards DJ, Porrata LF, Ythier A, Ferrande L, Nestorov I, Devries T, Dillon SR, Hausman D, Novak AJ 2008 Phase I clinical study of atacicep in patients with relapsed and refractory B-cell non-Hodgkin's lymphoma. Clin Cancer Res 14:1105-1110

76. Dall'Era M, Chakravarty E, Wallace D, Genovese M, Weisman M, Kavanaugh A, Kalunian K, Dhar P, Vincent E, Pena-Rossi C, Wofsy D 2007 Reduced B lymphocyte and immunoglobulin levels after atacicept treatment in patients with systemic lupus erythematosus: results of a multicenter, phase Ib, double-blind, placebo-controlled, dose-escalating trial. Arthritis Rheum 56:4142-4150

77. Nestorov I, Munafo A, Papasouliotis O, Visich J 2008 Pharmacokinetics and biological activity of atacicept in patients with rheumatoid arthritis. J Clin Pharmaco 48:406-417

78. Tak PP, Thurlings RM, Rossier C, Nestorov I, Dimic A, Mircetic V, Rischmueller M, Nasonov E, Shmidt E, Emery P, Munafo A 2008 Atacicept in patients with rheumatoid arthritis: results of a multicenter, phase $\mathrm{Ib}$, double-blind, placebocontrolled, dose-escalating, single- and repeated-dose study. Arthritis Rheum 58:61-72 